\title{
Incorporating graphene oxide into biomimetic nano-microfibrous cellulose scaffolds for enhanced breast cancer cell behavior
}

\author{
Yizao Wan • Zhonghong Lin • Quanchao Zhang • Deqiang Gan • \\ Miguel Gama $\cdot$ Junpin Tu $\cdot$ Honglin Luo
}

Received: 8 July 2019/Accepted: 22 February 2020/Published online: 3 March 2020

(C) Springer Nature B.V. 2020

\begin{abstract}
The impact of graphene oxide (GO) on normal cells has been widely investigated. However, much less is known on its effect on cancer cells. Herein, GO nanosheets were incorporated into electrospun cellulose acetate (CA) microfibers. The GOincorporated $\mathrm{CA}(\mathrm{GO} / \mathrm{CA})$ microfibers were combined with bacterial cellulose $(\mathrm{BC})$ nanofibers via in situ biosynthesis to obtain the nano-microfibrous scaffolds. The GO/CA-BC scaffolds were characterized by scanning electron microscopy (SEM), Fourier transform infrared spectroscopy (FTIR), thermogravimetric analysis (TGA), Raman spectroscopy, and X-ray photoelectron spectroscopy (XPS). The GO/
\end{abstract}

CA-BC scaffolds were used for breast cancer cell culture to evaluate the effect of GO on cancer cell behavior. Fluorescence images revealed large multicellular clusters on the surface of GO/CA-BC scaffolds. Compared to the bare $\mathrm{CA}-\mathrm{BC}$ scaffold, the $\mathrm{GO} /$ CA-BC scaffolds not only showed enhanced mechanical properties but also improved cell proliferation. It is expected that the GO/CA-BC scaffolds would provide a suitable microenvironment for the culture of cancer cells which is necessary for drug screening and cell biology study.
Electronic supplementary material The online version of this article (https://doi.org/10.1007/s10570-020-03078-w) contains supplementary material, which is available to authorized users.

Y. Wan · Z. Lin · Q. Zhang · D. Gan · J. Tu · H. Luo Institute of Advanced Materials, East China Jiaotong University, Nanchang 330013, China

Y. Wan · H. Luo ( $\bowtie)$

School of Materials Science and Engineering, Tianjin University, Tianjin 300072, China

e-mail: hlluotju@126.com

M. Gama

Centro de Engenharia Biológica, Universidade do Minho, Campus de Gualtar, 4715-057 Braga, Portugal 


\section{Graphic abstract}
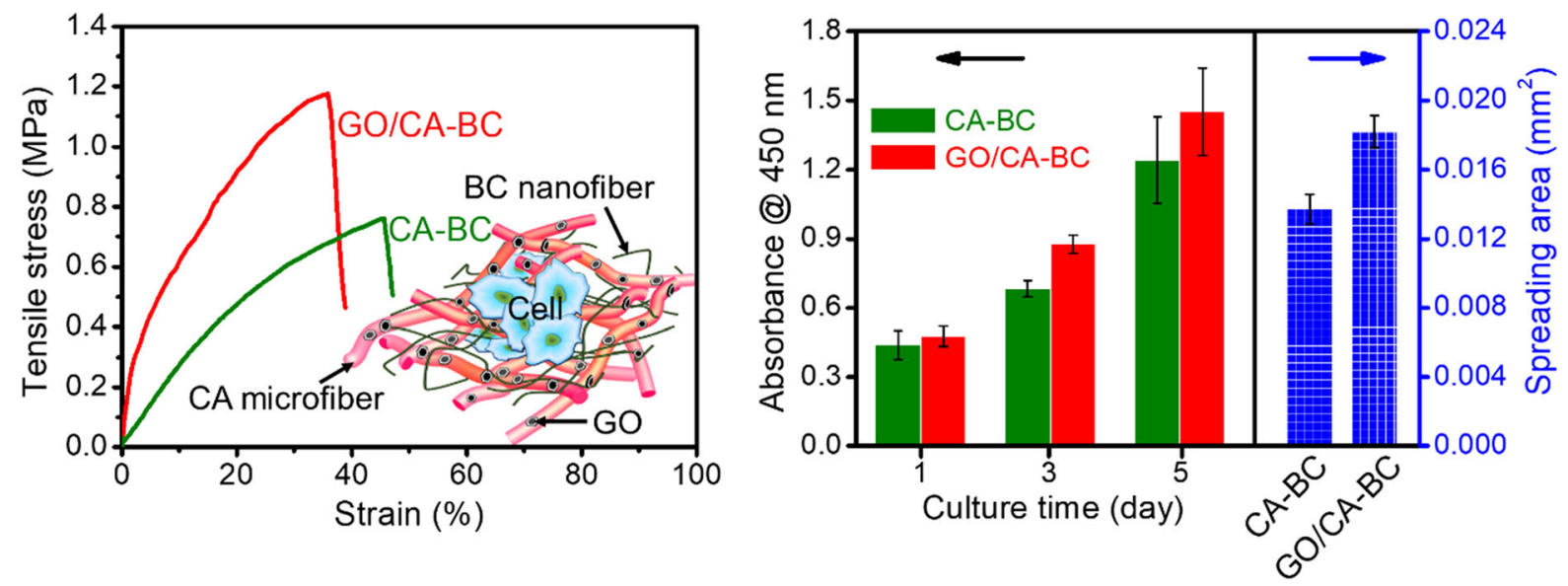

Adding GO in CA-BC nano-microfibrous scaffolds improves mechanical properties and cell proliferation

Keywords Biomaterials · Fibers · Biomimetic · Cellulose $\cdot$ Biocompatibility $\cdot$ Mechanical properties

\section{Introduction}

Graphene oxide (GO) is a biocompatible material with unique characteristics (Chang et al. 2011; Liao et al. 2011; Wojtoniszak et al. 2012). Unlike hydrophobic graphene and carbon nanotube, GO possesses good hydrophilicity and high reactivity thanks to the presence of abundant oxygen-containing groups, such as hydroxyl, epoxide, and carboxyl (Park and Ruoff 2009; Soldano et al. 2010). These functional groups can not only improve the dispersion of GO in the polymers (Verdejo et al. 2011; Young et al. 2012), but also lead to enhanced mechanical properties of the GO-incorporated polymer composites over pristine polymers due to the interfacial interaction between GO and polymers (Young et al. 2012; Zhu et al. 2010). Therefore, GO is believed to be an ideal reinforcing agent for composites (Da et al. 2012). For instance, Depan et al. reported the improvement of the mechanical properties in chitosan scaffolds through incorporation of GO (Depan et al. 2011). The GO/poly(vinyl alcohol) nanofibrous scaffolds fabricated by Qi et al. showed improved tensile strength and modulus over neat poly(vinyl alcohol) (Qi et al. 2013). Pinto et al. reported increased mechanical properties and higher barrier to gases by adding GO to poly(lactic acid)
(Pinto et al. 2013). Our previous work also demonstrated that incorporation of GO significantly improved the mechanical properties of sodium alginate (Mu et al. 2014) and bacterial cellulose (BC) ( $\mathrm{Si}$ et al. 2014; Luo et al. 2018a).

More importantly, apart from mechanical properties, GO could improve adhesion and proliferation of different kinds of cells such as L-929 (Chen et al. 2008), MC3T3-E1 (Liang et al. 2018; Fu et al. 2017), Schwann (Li et al. 2016; Jin et al. 2015), and stem cells (Jin et al. 2015; Kim et al. 2017; Mazaheri et al. 2014). Depan et al. observed improved cell attachment, proliferation, and cell growth on GO-incorporated chitosan scaffolds (Depan et al. 2011) and improved proliferation of osteoblasts was also reported on $\mathrm{GO} /$ poly(vinyl alcohol) nanofibrous scaffolds (Qi et al. 2013). Akhavan et al. reported that GO foam induced effective proliferation and differentiation of the human neural stem cells (hNSCs) (Akhavan et al. 2016). Cao et al. found that the scaffold consisting of chitosan/poly(vinyl alcohol)/GO nanofibers could deliver more appropriate environment for the growth of mouse chondrogenic cells (ATDC5) when compared with chitosan/poly(vinyl alcohol) (Cao et al. 2017). Shao and co-workers claimed enhanced bone formation in electrospun poly(L-lactic-co-glycolic acid)-tussah silk fibroin ultrafine nanofiber scaffolds incorporated with GO (Shao et al. 2016). Very interestingly, Kenry et al. demonstrated that the GO film selectively accelerated the proliferation of both metastatic and nonmetastatic breast cancer cells, but 
not that of noncancer breast epithelial cells (MCF10A) (Kenry et al. 2016). In spite of these achievements, no report can be found regarding the effect of GO on cancer cell behavior when it is incorporated into a structurally biomimetic scaffold, which has hierarchical structure (varying collagen fibril diameters) similar to natural extracellular matrix (ECM) in some tissues such as muscles, blood vessels, bones, skins, and neural networks (Xu et al. 2017; Du et al. 2019).

In this work, GO was incorporated into cellulose acetate (CA) microfibers by electrospinning. The GOincorporated (GO/CA) microfibers were then impregnated with the culture medium of bacterial cellulose (BC), thus yielding novel nano-microfibrous $\mathrm{GO} / \mathrm{CA}-$ $\mathrm{BC}$ scaffolds via in situ biosynthesis (Luo et al. 2018a, b). The as-prepared GO/CA-BC scaffolds with interpenetrated nano $(\sim 43-50 \mathrm{~nm})$ and micron $(0.87-2.21 \mu \mathrm{m})$ fibers were seeded with human breast cancer cells and the effect of GO on cell adhesion, growth, and proliferation was assessed.

\section{Materials and methods}

Fabrication of GO-incorporated electrospun CA microfibrous scaffolds

CA $\left(\mathrm{Mn}=4.0 \times 10^{4} \mathrm{~g} \mathrm{~mol}^{-1}\right)$ was supplied by Shanghai Aladdin Bio-Chem Technology Co. Ltd., Shanghai, China. The CA solution with a concentration of $16 \%(\mathrm{w} / \mathrm{v})$ was obtained by dissolving $1.2 \mathrm{~g}$ of CA into $7.5 \mathrm{~mL}$ of mixture of acetone/acetic acid/ dichloromethane (volume ratio 2/2/1) under constant stirring for $5 \mathrm{~h}$. Subsequently, GO (thickness: 0.6-1.2 nm, lateral dimension: $0.5-5 \mu \mathrm{m}$, obtained from Nanjing XFNANO Materials Technology Co. Ltd., Nanjing, China) aqueous solution $\left(2 \mathrm{mg} \mathrm{mL}^{-1}\right)$ was added to the above CA solution and stirred for $5 \mathrm{~h}$ at room temperature. Then, electrospinning was conducted at an applied voltage of $11 \mathrm{kV}$ and a dispensing rate of $0.3 \mathrm{~mL} \mathrm{~h}^{-1}$. An aluminum roller acted as collector at a distance to the needle of $15 \mathrm{~cm}$. The temperature was kept at $25-30{ }^{\circ} \mathrm{C}$ and the relative humidity at $30-35 \%$. Microfibrous scaffolds were obtained (named CA, GO/CA-1, GO/CA-2, and GO/ CA-3 with a GO content of $0,0.1,0.3$, and $0.5 \mathrm{wt} \%$, respectively) and were vacuum dried to remove the trace residual solvent.
Preparation of GO/CA-BC scaffolds

Figure 1 presents the fabrication procedures of $\mathrm{GO} /$ CA-BC scaffolds by the combined electrospinning and in situ biosynthesis. Briefly, a BC pellicle around $1 \mathrm{~mm}$ in thickness was first prepared by conventional static culture using the bacterial strain Komagataeibacter xylinus X-2. The culture medium was composed of $2.5 \%(\mathrm{w} / \mathrm{v})$ glucose, $0.75 \%(\mathrm{w} / \mathrm{v})$ yeast extract, $1 \%(\mathrm{w} / \mathrm{v})$ tryptone, and $1 \%(\mathrm{w} / \mathrm{v}) \mathrm{Na}_{2} \mathrm{HPO}_{4}$ and sterilized at $121{ }^{\circ} \mathrm{C}$ for $30 \mathrm{~min}$, as described previously (Wan et al. 2006, 2007, 2015). The thin BC pellicle obtained was used as the substrate for the preparation of GO/CA-BC scaffolds. Typically, the electrospun $\mathrm{GO} / \mathrm{CA}$ microfibrous scaffold was placed on top of the BC pellicle. Afterwards, the culture medium was sprayed into the GO/CA microfibrous scaffold standing on BC substrate followed by in situ BC growth inside the GO/CA scaffold until growth completion. Immediately afterwards, the second cycle of spraying and growing was initiated. The spraying and growing cycle stopped when the fifth cycle was completed, each one lasting around $1 \mathrm{~h}$. The harvested GO/CA-BC scaffolds with interpenetrated structure of $\mathrm{BC}$ nanofibers and $\mathrm{GO} / \mathrm{CA}$ microfibers was purified by soaking in deionized water at $90{ }^{\circ} \mathrm{C}$ for $2 \mathrm{~h}$, boiled in a $0.5 \mathrm{M} \mathrm{NaOH}$ solution for $15 \mathrm{~min}$, and then washed several times with abundant deionized water until neutrality. The thickness of the resultant $\mathrm{GO} /$ CA-BC hydrogel was around $1 \mathrm{~mm}$ after removing BC substrate. Finally, the GO/CA-BC scaffolds $\left(50 \times 40 \times 1 \mathrm{~mm}^{3}\right)$ were purified, as reported previously (Luo et al. 2017, 2018a; Wan et al. 2007, 2018). Some hydrogel samples were freeze dried for characterization. The same procedure was employed to produce a CA-BC scaffold for control.

Characterization methods

The morphology of GO was characterized by atomic force microscopy (AFM, Agilent 5500, Agilent Technologies). The morphology of the scaffolds (freeze dried samples) was observed by scanning electron microscopy (SEM, FEI Nano 430). The average fiber diameter was measured using the Nano Measure1.2 software by randomly selecting at least 100 fiber segments as reported in our previous work (Wan et al. 2015), and, similarly, the pore size was obtained by measuring at least 200 randomly selected 


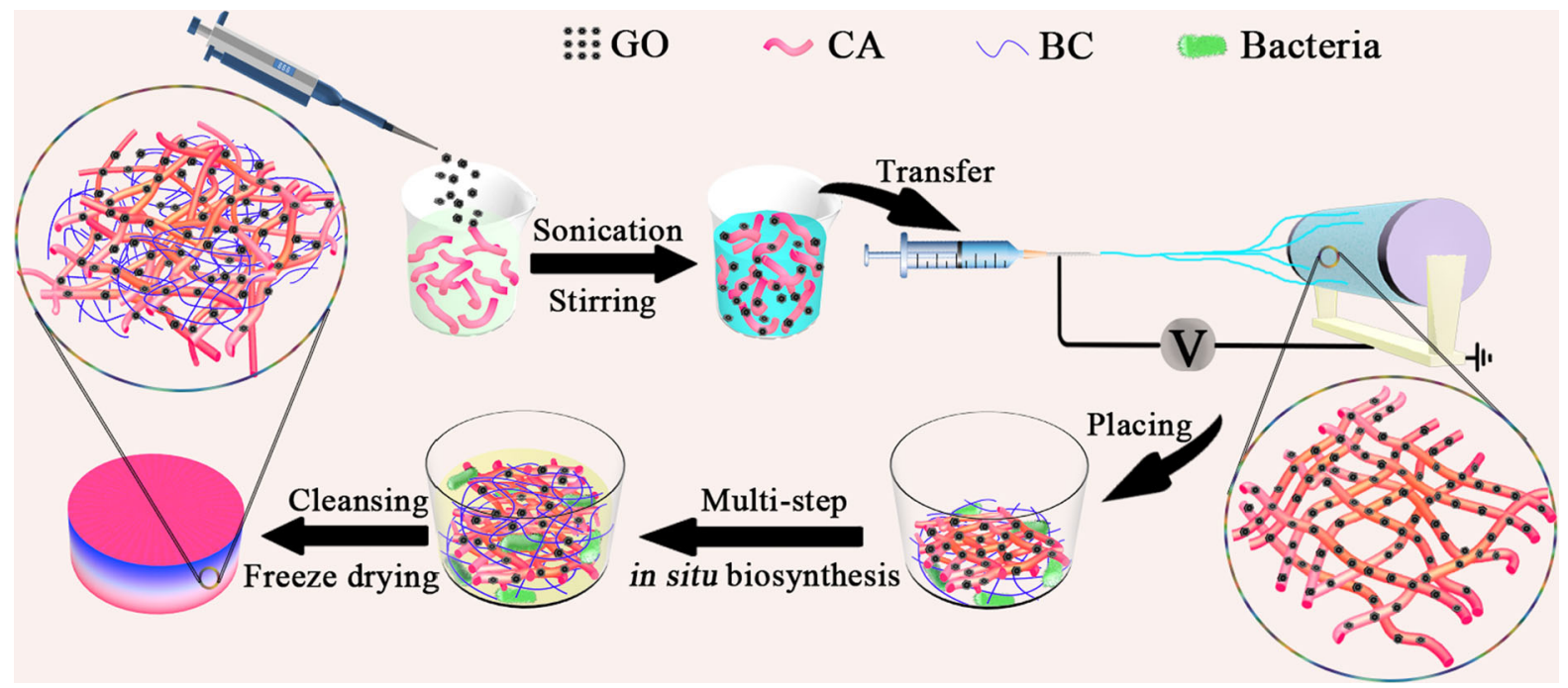

Fig. 1 Preparation procedures of GO/CA-BC scaffolds

pores. X-ray diffraction (XRD) analysis was conducted to determine the crystalline structure of $\mathrm{GO} /$ CA-BC scaffolds using a Rigaku D/max 2500 X-ray diffractometer using $\mathrm{Cu}-\mathrm{K} \alpha$ radiation $(\lambda=0.154 \mathrm{~nm})$. Fourier transform infrared spectroscopy (FTIR) was performed using a Perkin-Elmer Spectrum One spectrometer. Water contact angles of scaffold materials (after pressing at room temperature in order to produce flat surfaces) were measured using contact angle meter (Dropmaster 300, Japan).

To measure the mechanical properties of various scaffold materials, hydrogel samples with dimensions of $10 \times 5 \times 1 \mathrm{~mm}^{3}$ were tested by a micro-electromagnetic fatigue testing machine (MUF-1050, Tianjin Care Measure \& Control Co., Ltd., Tianjin, China). The strain rates were $0.08 \mathrm{~mm} \mathrm{~s}^{-1}$ in each case. At least five specimens from each group were chosen for the tensile test, and the averages and standard deviations were reported.

\section{Cell studies}

\section{Cell culture and seeding on scaffolds}

The human breast cancer cell line (MCF-7) obtained from Shanghai cell bank of Chinese Academy of Sciences, was used in this work. The MCF-7 cells (passaged to the seventh generation) were cultured in Dulbecco's modified eagle medium (DMEM, Hyclone, America) supplemented with $10 \%$ fetal bovine serum (FBS, Gibco, South America) in a humidified incubator with $5 \% \mathrm{CO}_{2}$ at $37{ }^{\circ} \mathrm{C}$.

Circular scaffolds with a thickness of $1 \mathrm{~mm}$ and a diameter of $15 \mathrm{~mm}$ were sterilized at $121^{\circ} \mathrm{C}$ for $30 \mathrm{~min}$. Then the scaffolds were placed into 24 -well culture plates and seeded at a cell density of $1 \times 10^{4}$ cells per well, followed by incubation in a $5 \% \mathrm{CO}_{2}$ incubator at $37{ }^{\circ} \mathrm{C}$ filled with DMEM supplemented with $10 \%$ FBS. The culture medium was renewed every other day. The cell-loaded scaffolds were removed at specific intervals to examine cell attachment, morphology, and proliferation with fluorescence, SEM, and cell counting kit-8 (CCK-8).

\section{Cell viability assay}

Cellular viability was measured using CCK-8 assay at the first, third, and fifth day of culture. Following incubation, $200 \mu \mathrm{L}$ of medium (containing 10\% CCK8 reagent) was added to each well and plates were incubated in darkness for $2 \mathrm{~h}$ at $37{ }^{\circ} \mathrm{C}$. After the culture medium was transferred to 96 -well plates, the absorbance was read at $450 \mathrm{~nm}$ using microplate reader (iMark, Bio Rad, USA).

\section{Live staining}

After cell culturing under the above-mentioned conditions, the scaffolds were rinsed with phosphate buffered saline (PBS) and then stained with 
fluorescein diacetate (FDA). After incubation for another $2 \mathrm{~min}$, the stained cultures were observed under a fluorescence microscope (Nikon, ECLIPSE Ts2R, Japan).

\section{Cell adhesion and morphology}

SEM was used to observe the cell adhesion and morphology. The MCF-7 cells were cultured on the scaffolds and incubated in DMEM supplemented with $10 \%$ FBS at $37^{\circ} \mathrm{C}$ for 5 days. The constructs with cells were then gently washed 3 times with PBS, fixed with $2 \%$ glutaraldehyde at $4{ }^{\circ} \mathrm{C}$ for $12 \mathrm{~h}$ and then dehydrated through gradient ethanol solutions $(50,60$, $70,80,90,95$, and $100 \%$ ). Immediately afterwards, the ethanol was replaced with hexamethyl disilylamine to preserve the morphology of cells. Finally, the scaffolds with cells were coated with a layer of gold and observed by SEM. From the SEM images, the cell area (in $\mu \mathrm{m}^{2}$ ) was defined as the area covered by the cell projected over the substrate (Collartdutilleul et al. 2014; Galli et al. 2016).

\section{Statistical analysis}

The experimental data was analyzed using an SPSS software (version 20) and a one way ANOVA with least-significant difference (LSD) post hoc was used to determine the presence of any significant differences between different sample groups. Statistically significant differences were accepted as $p$ value $\leq 0.05$.

\section{Results and discussion}

Morphology

As shown in Fig. S1 (Supplementary Material), GO was about $500 \mathrm{~nm}$ in size and $0.6 \mathrm{~nm}$ in thickness, thus consisting of single layer sheets, consistent with the specifications provided by the supplier.

The SEM images together with fiber diameter distribution and digital photos of $\mathrm{CA}-\mathrm{BC}, \mathrm{GO} / \mathrm{CA}-$ BC-1, GO/CA-BC-2, and GO/CA-BC-3 composites are illustrated in Fig. 2. As expected, the sample color becomes darker as GO content increases in CA (Fig. 2a). The SEM image of CA-BC scaffold shows two different kinds of fibers (Fig. 2b), one being nanofibers with an average diameter of $43.50 \mathrm{~nm}$, the other being microfibers with an average diameter of $2.21 \mu \mathrm{m}$ (Fig. 2c). Clearly, the entangled structure is demonstrated in Fig. 2b. Such interpenetrated structure is beneficial to the improvement of mechanical properties. SEM images suggest that all GO/CA-BC scaffolds show similar structure with thick GO/CA microfibers entangled with fine BC nanofibers (Fig. 2b, e, h, k). Similar to previous reports (Ardeshirzadeh et al. 2015; Liu et al. 2014; Liu et al. 2017), GO is hardly detectable from SEM observation since these GO sheets are embedded inside the CA fibers during electrospinning. Fiber diameter distributions (Fig. 2c, f, i, h) reveals the continuous decrease of the average diameter of electrospun GO/CA fibers with increasing GO content. Furthermore, pore size measurements reveal that the incorporation of GO into CA-BC scaffold leads to a slight change in the pore structure (Fig. S2, Supplementary Material).

\section{Physiochemical properties}

Figure 3a presents the FTIR spectra of various materials. Powdery GO exhibits the characteristic peaks at $3432,1723,1630$, and $1096 \mathrm{~cm}^{-1}$ for O-H stretching, $\mathrm{C}=\mathrm{O}$ stretching vibration, and $\mathrm{C}=\mathrm{C}$ stretching, $\mathrm{C}-$ $\mathrm{O}-\mathrm{C}$ stretching vibration, respectively (Shao et al. 2016). CA shows O-H stretching at $3491 \mathrm{~cm}^{-1},-\mathrm{CH}_{2}$ asymmetric stretching at $2894 \mathrm{~cm}^{-1}, \mathrm{C}-\mathrm{O}-\mathrm{C}$ stretching at $1052 \mathrm{~cm}^{-1}$ (Uddin et al. 2016; Liu and Hsieh 2002), and $\mathrm{C}=\mathrm{O}$ in-plane stretching vibration at $1740 \mathrm{~cm}^{-1}$ which is an indication of the formation of ester group as a result of acetylation reaction (Kabiri and Namazi 2014). As expected, characteristic peaks at 3348,2890 , and $1061 \mathrm{~cm}^{-1}$ are observed in the spectrum of $\mathrm{BC}$, which correspond to $-\mathrm{OH}$ bonds, asymmetric stretching vibration of $\mathrm{C}-\mathrm{H}$, and antisymmetric bridge stretching of $\mathrm{C}-\mathrm{O}-\mathrm{C}$, respectively. These peaks are also observed in the spectra of $\mathrm{GO} /$ CA-BC. However, the peak at $1740 \mathrm{~cm}^{-1}$ in CA disappears in $\mathrm{GO} / \mathrm{CA}-\mathrm{BC}$ due to acetate hydrolysis in alkaline medium during purification of $\mathrm{BC}$, as previously reported by Liu et al. (Liu and Hsieh 2002). Compared with CA, a significant red shift for $-\mathrm{OH}$ groups is observed in $\mathrm{CA}-\mathrm{BC}$, which can be due to the formation of hydrogen bonding between $\mathrm{CA}$ and $\mathrm{BC}$ (Wan et al. 2018). There is also an obvious peak shift of $-\mathrm{OH}$ groups in $\mathrm{GO} / \mathrm{CA}$ as compared to the pristine materials, indicating the hydrogen bonding reaction between CA and GO. Similar interactions between 

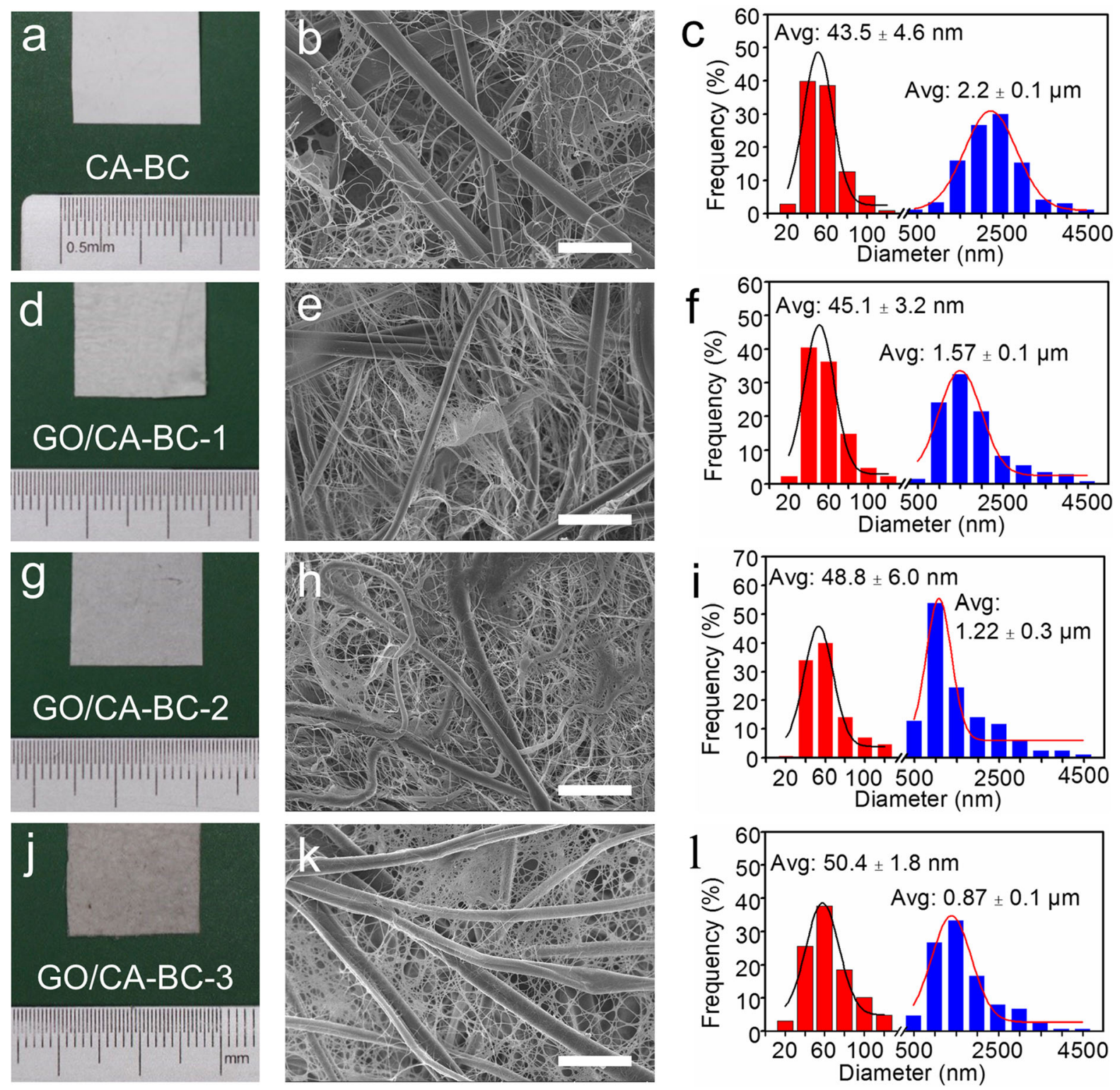

Fig. 2 Digital photos (a, d, g, j), SEM micrographs $(\mathbf{b}, \mathbf{e}, \mathbf{h}, \mathbf{k})$, and fiber diameter distribution $(\mathbf{c}, \mathbf{f}, \mathbf{i}, \mathbf{l})$ of CA-BC $(\mathbf{a}, \mathbf{b}, \mathbf{c}), \mathrm{GO} /$ CA-BC-1 (d, e, f), GO/CA-BC-2 (g, h, i), and GO/CA-BC-3 (j,

filler and polymer matrices, detected as a shift of $-\mathrm{OH}$ stretching band, have been noticed in several types of composites (Aboamera et al. 2018; Layek et al. 2018).

The crystalline structure of CA-BC and GO/CA$\mathrm{BC}$ materials was determined (Fig. 3b). The XRD pattern of $\mathrm{BC}$ is typical, showing three characteristic peaks at $14.6^{\circ}, 16.8^{\circ}$, and $22.8^{\circ}$, which correspond to the (1 $\overline{1} 0),(110)$, and (200) diffraction planes of cellulose, in line with previous studies (Luo et al. $\mathbf{k}, \mathbf{l})$ scaffolds prepared by electrospinning and in situ biosynthesis. Scale bar: $5 \mu \mathrm{m}$

2018b; Si et al. 2014; Tokoh et al. 1998). Likewise, GO shows a typical pattern with an intense characteristic peak at $2 \theta=11.5^{\circ}$, corresponding to its diffraction plane of (001), consistent with previous works (Blanton and Majumdar 2013). The XRD pattern of CA is also similar to previously reported results, showing two broad peaks at $2 \theta=9.6$ and $20^{\circ}$ (He et al. 2007). Obviously, the XRD pattern of CA-BC is approximately the mixture of $\mathrm{BC}$ and $\mathrm{CA}$ but without 


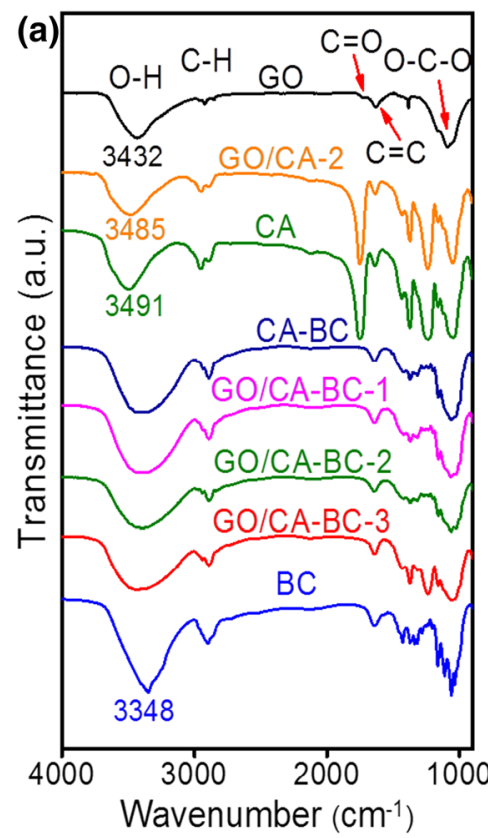

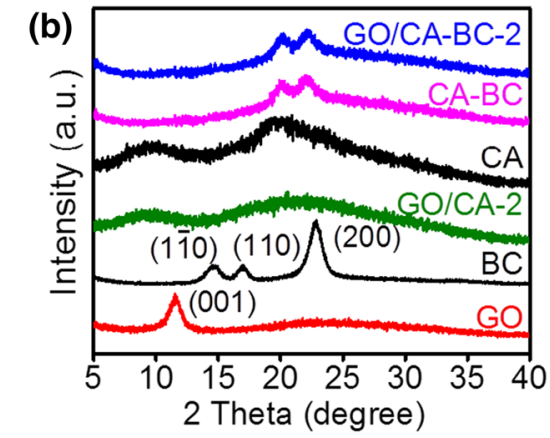

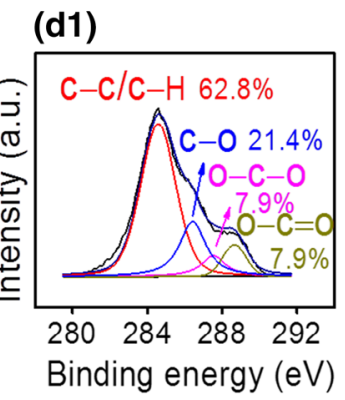

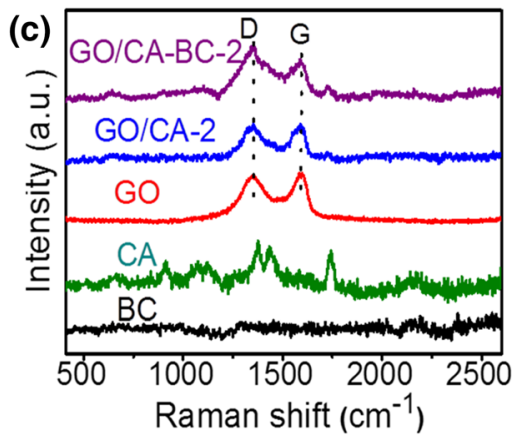

(d3)
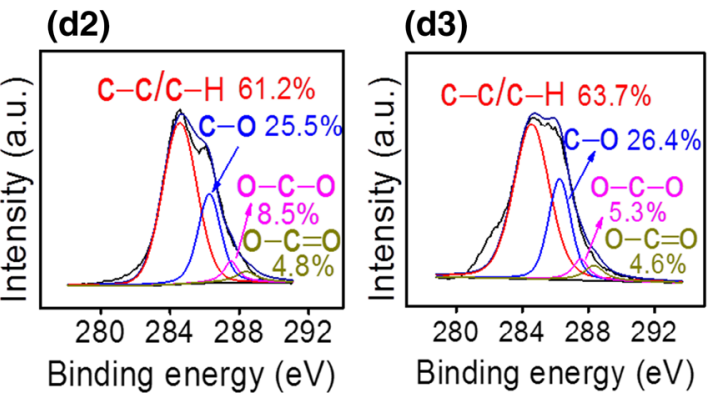

Fig. 3 FTIR (a), XRD (b), Raman (c), and XPS (d) results of relevant materials. Fitting results of C 1 s spectra of CA (d1), BC-CA (d2), and GO/CA-BC-2 (d3)

showing the weaker peaks of $\mathrm{CA}$ and $\mathrm{BC}$. The XRD pattern of GO/CA-BC-2 is almost identical to that of $\mathrm{CA}-\mathrm{BC}$ without showing the characteristic peak of $\mathrm{GO}$, due to the limited amount of GO (0.3 wt \%). Similarly, the XRD pattern of GO/CA-2 does not show the GO peak.

Raman spectroscopy was used to further confirm the existence of GO in the CA fibers and its structure. As shown in Fig. 3c, two characteristic peaks are observed at about 1345 and $1590 \mathrm{~cm}^{-1}$ in the Raman spectra of $\mathrm{GO}, \mathrm{GO} / \mathrm{CA}-2$, and $\mathrm{GO} / \mathrm{CA}-\mathrm{BC}-2$, which correspond to the $\mathrm{D}$ and $\mathrm{G}$ bands, respectively ( $\mathrm{Si}$ et al. 2014; Stankovich et al. 2007). It is noted that BC does not show any peak. Although, similar to a previous report (Baldino et al. 2015), there are peaks in the spectrum of CA, they do not contribute to D and G bands. These results confirm the presence of GO in GO/CA-2 and GO/CA-BC-2. The intensity ratio of the $\mathrm{D}$ band to the $\mathrm{G}$ band $\left(\mathrm{I}_{\mathrm{D}} / \mathrm{I}_{\mathrm{G}}\right.$, another parameter reflecting the structure of carbon materials and representing the disorder degree of carbon materials [3]) is calculated to be about 0.99 for $\mathrm{GO}$. The $\mathrm{I}_{\mathrm{D}} / \mathrm{I}_{\mathrm{G}}$ of $\mathrm{GO} /$ CA-2 is close to that value, indicating little effect of the electrospinning process on the structure and texture of GO. However, the $\mathrm{I}_{\mathrm{D}} / \mathrm{I}_{\mathrm{G}}$ of $\mathrm{GO} / \mathrm{CA}-\mathrm{BC}-2$ increases to 1.08 after the introduction of $\mathrm{BC}$. This effect can be assigned to the removal of some oxygencontaining functional groups on the surface of GO during washing in boiling $\mathrm{NaOH}$ solution (Fan et al. 2008; Si et al. 2014).

To determine the functional groups and bonding characteristics of the $\mathrm{CA}, \mathrm{CA}-\mathrm{BC}$, and $\mathrm{GO} / \mathrm{CA}-\mathrm{BC}$ materials, XPS analysis was carried out and the results are displayed in Fig. 3d, Fig. S3, and Table S1 (Supplementary Material). As shown in Fig. S3, the wide-scan spectra of the three materials are similar, showing the presence of $\mathrm{C}$ and $\mathrm{O}$ elements, as expected. Figure $3 \mathrm{~d} 1$ and Table $\mathrm{S} 1$ show that the high-resolution $\mathrm{C} 1 \mathrm{~s}$ of CA can be deconvoluted into four sub-peaks at 284.6, 286.4, 287.5, and $288.7 \mathrm{eV}$, which can be assigned to $\mathrm{C}-\mathrm{C}$ or $\mathrm{C}-\mathrm{H}(62.8 \%), \mathrm{C}-\mathrm{O}$ (21.4\%), $\mathrm{C}-\mathrm{O}-\mathrm{C}(7.9 \%)$, and $\mathrm{O}-\mathrm{C}=\mathrm{O}(7.9 \%)$ groups, respectively (Dorris and Gray 1978). As shown in Fig. 3d2 and Table S1, the deconvoluted results of the high-resolution $\mathrm{C} 1 \mathrm{~s}$ of $\mathrm{CA}-\mathrm{BC}$ show the same constitution of $\mathrm{C}-\mathrm{C} / \mathrm{C}-\mathrm{H}, \mathrm{C}-\mathrm{O}, \mathrm{C}-\mathrm{O}-\mathrm{C}$, and $\mathrm{O}-\mathrm{C}=\mathrm{O}$ groups. However, Table $\mathrm{S} 1$ reveals that the binding energies of $\mathrm{C}-\mathrm{O}$ and $\mathrm{O}-\mathrm{C}=\mathrm{O}$ in $\mathrm{CA}-\mathrm{BC}$ become lower than $\mathrm{CA}$, likely due to the hydrogen bonding interaction between $-\mathrm{OH}$ in $\mathrm{BC}$ and $\mathrm{O}-\mathrm{C}=\mathrm{O}$ in CA. This finding agrees well with the FTIR result. Furthermore, although there are no changes in the 
functional groups between $\mathrm{CA}-\mathrm{BC}$ and $\mathrm{GO} / \mathrm{CA}-\mathrm{BC}-$ 2 , a slight reduction in the binding energy of $\mathrm{O}-\mathrm{C}=\mathrm{O}$ is noted (Fig. 3d3 and Table S1), which can be attributed to the possible hydrogen bonding interaction between $-\mathrm{OH}$ and $\mathrm{O}-\mathrm{C}=\mathrm{O}$ in $\mathrm{CA}$ and GO. The XPS findings further confirm the interfacial interactions among the three components.

Prior to mechanical characterization, thermal stability of GO/CA-BC, GO, and CA-BC was measured, and the results are presented in Fig. S4 (Supplementary Material), which reveals that the three GO/CABC scaffold materials show similar TG curves to CA$\mathrm{BC}$, suggesting a negligible influence of GO due to its low amount in the composites.

The mechanical testing results are displayed in Fig. 4. As shown in Fig. 4a, the tensile stress-strain curves of four scaffold materials suggest that their maximum stress and strain at break are different. Moreover, Fig. 4b-d reveals that the differences in tensile strength, tensile modulus, and strain at break

(a)

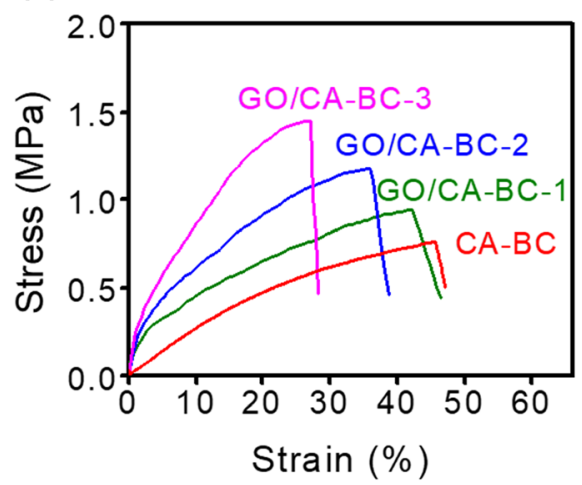

(c)

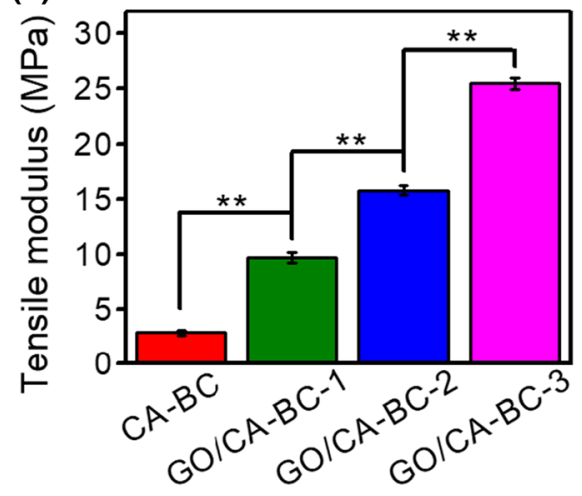

Fig. 4 Tensile properties of CA-BC and GO/CA-BC scaffold materials. a Typical stress-strain curves, b Tensile strength, c Tensile modulus, $\mathbf{d}$ Strain at break. The values are expressed as are significant $(p<0.01)$ among four scaffold materials except for strain at break between $\mathrm{CA}-\mathrm{BC}$ and GO/CA-BC-1 $(p>0.05)$. Figure $4 \mathrm{~b}$ reveals an increasing trend of tensile strength with GO content in the composites. The GO/CA-BC-3 with 0.5 wt \% GO shows an $83 \%$ improvement in tensile strength as compared to bare $\mathrm{CA}-\mathrm{BC}$. The change of tensile modulus with GO content exhibits the same trend (Fig. 4c), while the reverse is observed for the strain at break (Fig. 4d).

Wettability is a critical parameter, concerning the use of the scaffolds for cell culture. Thus, we tested the water contact angles of various scaffolds. Fig. S5 (Supplementary Material) reveals that all materials except $\mathrm{CA}$ are hydrophilic $\left(\mathrm{GO}=64.1^{\circ}, \mathrm{CA}=\right.$ $124.5^{\circ}, \mathrm{BC}=37.6^{\circ}, \mathrm{CA}-\mathrm{BC}=55.7^{\circ}, \mathrm{GO} / \mathrm{CA}-\mathrm{BC}-$ $1=45.8^{\circ}, \quad \mathrm{GO} / \mathrm{CA}-\mathrm{BC}-2=42.6^{\circ}, \quad \mathrm{GO} / \mathrm{CA}-\mathrm{BC}-$ $3=38.8^{\circ}$ ) with water contact angles of $\angle 90^{\circ}$ due to the good hydrophilicity of BC. The GO/CA-BC

(b)
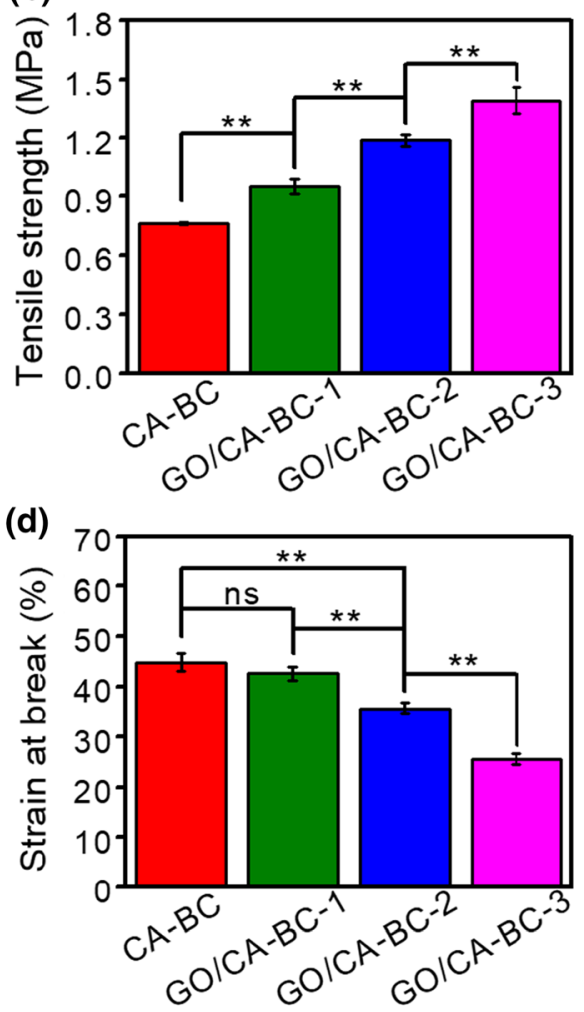

mean $\pm \mathrm{SD}$. Significance was defined as $* * p<0.01, \mathrm{n}=5$. ns represents not significant, $p>0.05$ 
materials are significantly more hydrophilic than the bare CA-BC $(p<0.05)$.

\section{Cell studies}

To evaluate the cytotoxicity of various scaffolds, the cellular viabilities of MCF-7 cells incubated on the $\mathrm{CA}-\mathrm{BC}$ and $\mathrm{GO} / \mathrm{CA}-\mathrm{BC}$ scaffolds were determined via the CCK-8 assay (Fig. 5). The MCF-7 cells on the four scaffolds show progressive increase over time in optical density (OD), an indication of cell viability, suggesting robust proliferation. At day 1,3 and 5, GO/ CA-BC-2 shows significantly higher OD than other composite scaffolds, suggesting an optimal GO for cell proliferation.

The biocompatibility was also analyzed by fluorescence (viability) staining. Figure 6 shows images of MCF-7 cells cultured on various scaffolds. The cells exhibit good adherence, spreading, and robust growth on all scaffolds. The number of cells increases continuously. These results are in accordance with cell viability assay results shown in Fig. 5, although quantitative comparisons cannot be made.

To determine cell ingrowth inside the scaffolds, laser confocal microscope was used. As seen in Fig. 7, many cell clusters are found inside all scaffolds. To further assess the cell proliferation behavior, cell number was counted from the confocal images (Fig. S6, Supplementary Material). The number of

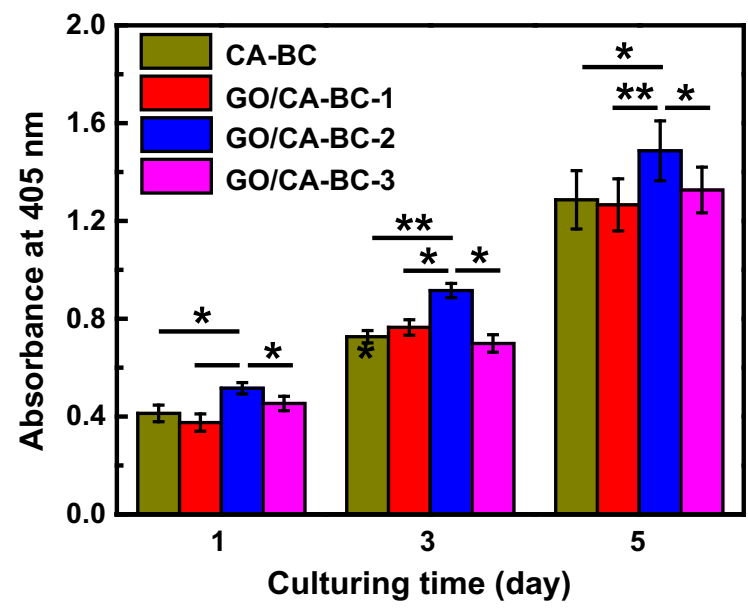

Fig. 5 Cell viability assay results of MCF-7 breast cancer cells cultured on $\mathrm{CA}-\mathrm{BC}$ and $\mathrm{GO} / \mathrm{CA}-\mathrm{BC}$ scaffolds for 1,3 , and 5 days. The asterisk $(*)$ indicates statistically significant differences for $p$-values $<0.05$, double asterisks $(* *)$ indicate statistically significant differences for $p$-values $<0.01$ cells per $\mathrm{mm}^{3}$ scaffolds is $126,133,197$, and 161 for CA-BC, GO/CA-BC-1, GO/CA-BC-2, and GO/CA$\mathrm{BC}-3$, respectively. This result suggests that incorporation of $\mathrm{GO}$ into $\mathrm{CA}-\mathrm{BC}$ promotes cell proliferation.

SEM was used to further observe the morphology of MCF-7 cells cultured on scaffolds (Fig. 8). Although no significant difference in cell morphology can be discerned among four scaffolds, the cells on these scaffolds show robust proliferation with spreadout appearances as well as abundant leafy protrusions (Fig. 8a-d) either at day 3 or day 5, which is an indication of good cell attachment. Furthermore, as shown in Fig. 8e, the spreading area is different among these scaffolds. The GO/CA-BC-2 shows the largest spreading area among these scaffolds.

\section{Discussion}

An ideal artificial scaffold (for the culture of either cancer or normal cells) should have a suitable structure to mimic ECM such that cellular behavior can be promoted. In this study, to obtain an ideal scaffold with ECM-like morphology and favorable mechanical properties, GO-impregnated biomimetic scaffolds composed of GO/CA microfibers and $\mathrm{BC}$ nanofibers have been fabricated via the combined electrospinning and in situ biosynthesis process. The aim of this work was to evaluate the influence of GO incorporation into CA on morphology and physiochemical properties as well as cell adhesion, spreading, and proliferation.

First, we find that the morphology of GO/CA microfibers is not significantly affected by GO incorporation except that the CA fiber diameter decreases with the GO content. This is due to the higher viscosity when more GO is added to CA solutions (Liu et al. 2014). Interestingly, SEM observations reveal the interpenetrated structure of $\mathrm{BC}$ nanofibers (with an average diameter of $43-50 \mathrm{~nm}$ ) and GO/CA microfibers (with a diameter of $0.87-2.2 \mu \mathrm{m}$ ). Such morphology is similar to native ECM in muscles, blood vessels, bones, skins, and so on (Xu et al. 2017; Du et al. 2019) in which collagen fibrils have a varying diameter ranging from tens to hundreds of nanometers (Rho et al. 2006). In addition, to strengthen the CABC scaffold, we have incorporated GO into the CA microfibers and significantly improved mechanical properties are achieved. The reinforcing effect of GO nanosheets in polymer matrix composites has been 


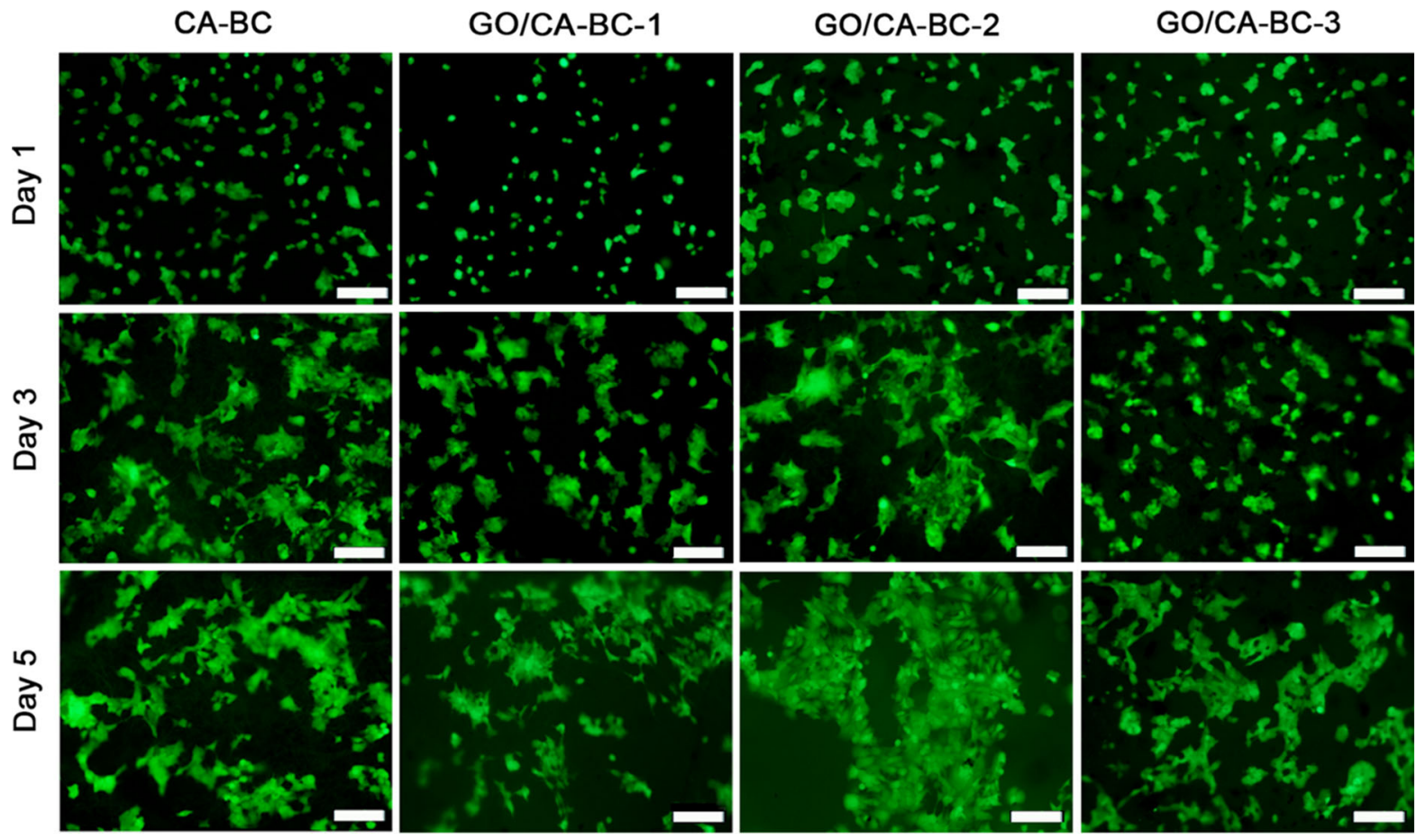

Fig. 6 Representative fluorescence microscopy images showing the viability of MCF-7 breast cancer cells cultured on different scaffolds. FDA was used to stain the live cells. All scale bars represent $100 \mu \mathrm{m}$
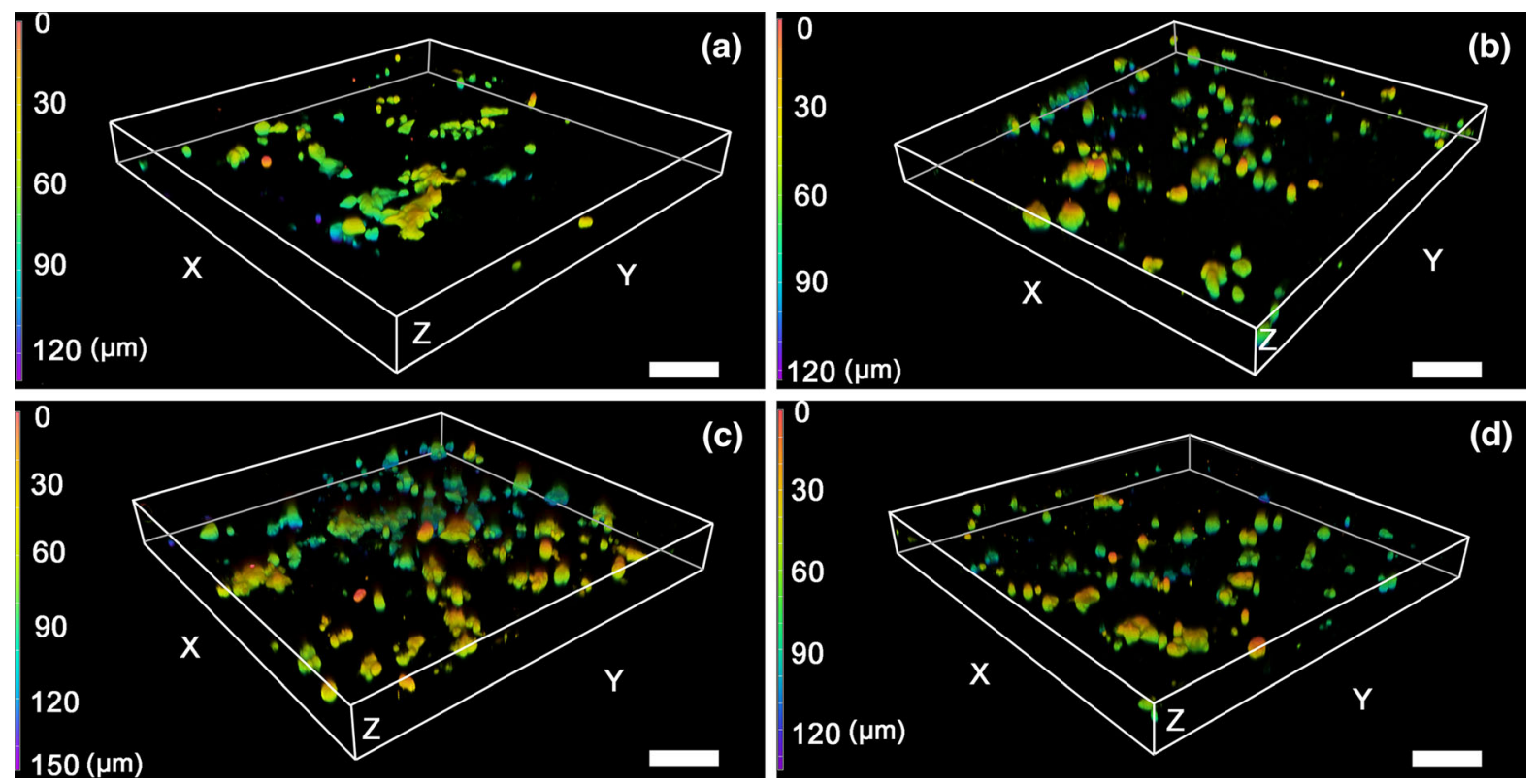

Fig. 7 Laser confocal microscopic images of MCF-7 cells after proliferation for 3 days on CA-BC (a), GO/CA-BC-1 (b), GO/CABC-2 (c), and GO/CA-BC-3 (d) scaffolds. Scale bar: $100 \mu \mathrm{m}$

well documented. The interactions between the polymer matrix and GO are believed to restrict the movement of the polymer chains and increase their entanglement, thus enhancing strength while reducing 
Fig. 8 SEM images (a-d) and cell spreading area $(\mathbf{e})$ of MCF-7 cells seeded on CA$\mathrm{BC}$ (a), GO/CA-1 (b), GO/ CA-2 (c), and GO/CA-3 (d) scaffolds for 3 (upper row) and 5 (bottom row) days. The asterisk $(*)$ indicates statistically significant differences for $p<0.05$, while double asterisks $(* *)$ indicate statistically significant differences for $p<0.01$, scale bar: $50 \mu \mathrm{m}$
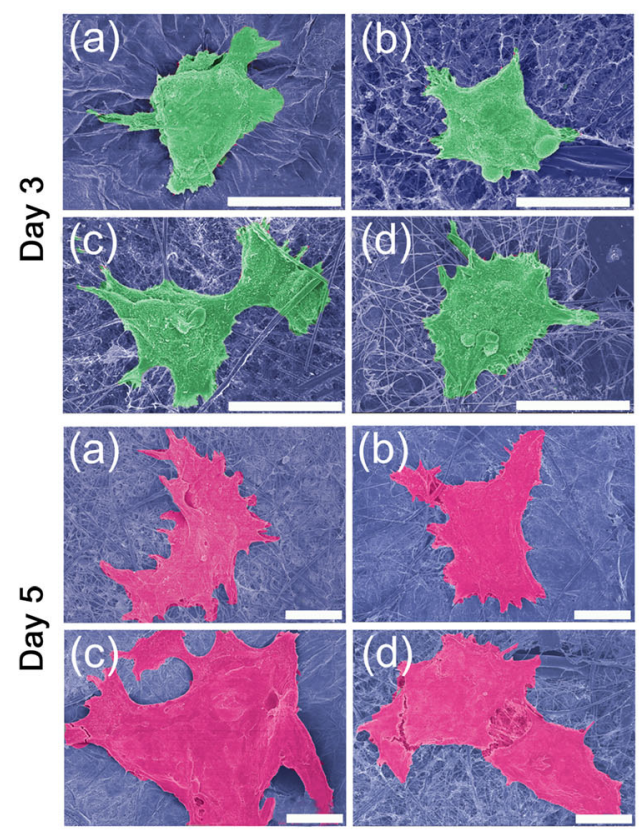

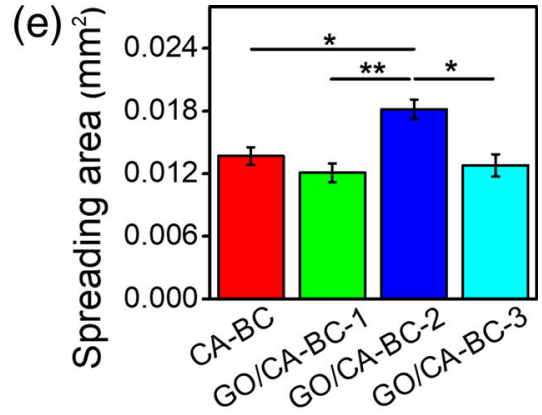

(e)

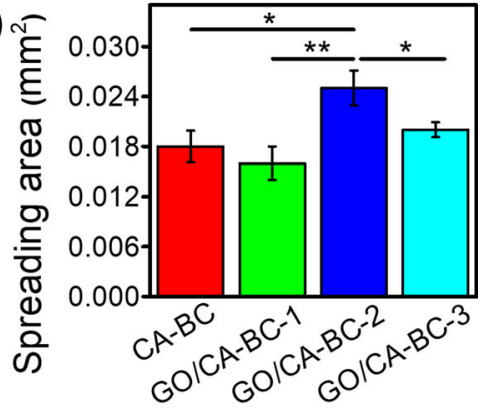

ductility (Potts et al. 2011). In the present GO/CA-BC composites, the significant improvements in tensile strength and modulus can be attributed to the interfacial interaction between $\mathrm{CA}$ and $\mathrm{GO}$, as suggested by FTIR and XPS analyses and the mechanical entanglement between GO/CA microfibers and BC nanofibers.
The proposed mechanisms are schematically illustrated in Fig. 9.

We then compared the attachment, spreading, proliferation, and morphology of MCF-7 cells seeded on different scaffolds. Our main finding is that GO incorporation significantly influences the behavior of MCF-7 cells that adhere and proliferate on different

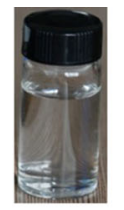

CA
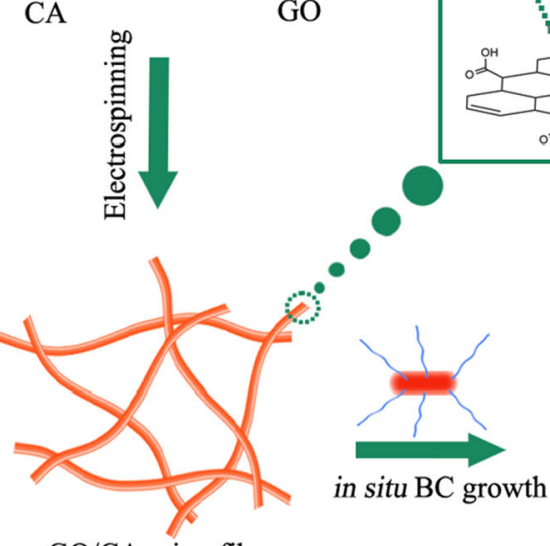

$\mathrm{GO} / \mathrm{CA}$ microfibers

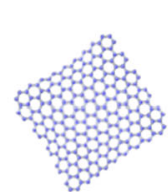

GO
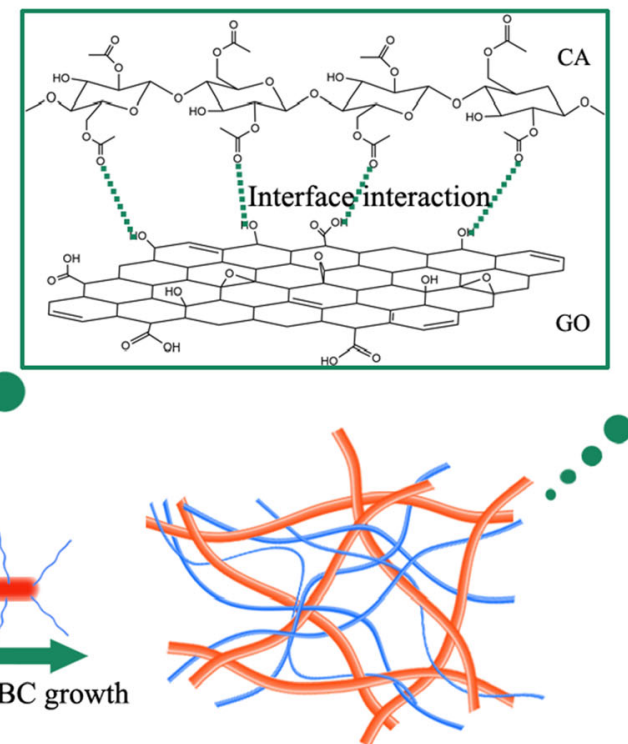

Entanglement of $\mathrm{GO} / \mathrm{CA}$ and $\mathrm{BC}$
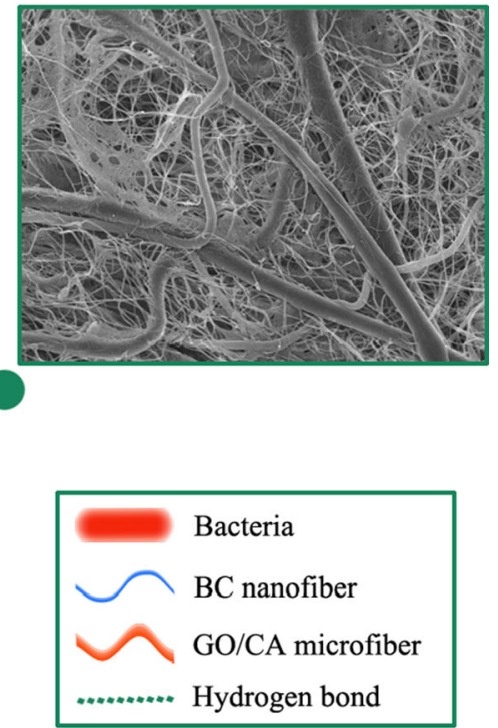

Hydrogen bond

Fig. 9 A schematic illustration showing the improved mechanical properties of GO/CA-BC materials 
scaffolds. Although both CCK-8 and live cell staining demonstrate progressive cell proliferation on all scaffolds, quantitative CCK-8 assay and spreading calculation indicate more robust cell proliferation on and inside GO/CA-BC-2 scaffold. These results suggest that the GO/CA-BC-2 scaffold is very promising in providing favorable microenvironment for cancer cells. All together, the combined results of cell studies demonstrate that GO incorporation into biomimetic scaffolds can lead to improved proliferation of cancer cells.

We believe that the improved cancer cell attachment, spreading, and proliferation can be attributed to the following two aspects. On the one hand, the biomimetic nano-micron morphology contributes to the good cell functions. Although there is no report on cancer cells cultured in nano-microfibrous scaffolds, a few previous studies confirmed the suitability of nanofibrous scaffolds for cancer cell growth and survival (Sims-Mourtada et al. 2014; Kazantseva et al. 2018; Bae et al. 2011), which indicates that both normal and cancerous tissues are responsive to ECMlike microenvironments. Here, we combine nanofibers with microfibers to provide a more elaborate ECMlike microenvironment than single nanofibers or microfibers. Thus, MCF-7 cells cultured on the nano-microfibrous scaffolds display persistent proliferation, which may significantly improve the cell-cell and cell-ECM communications. On the other hand, GO incorporation is responsible for such improvements, which has been demonstrated by many previous studies (Kenry et al. 2018; Akhavan et al. 2016).

Furthermore, we also find that cancer cell spreading and proliferation are dependent on the GO content. The GO-dependent toxicity has been well documented in literature (Mohammadrezaei et al. 2018). Mazaheri et al. reported a GO content-dependent proliferation of stem cells (Mazaheri et al. 2014). Ordikhani et al. found that the $\mathrm{GO} /$ chitosan is highly biocompatible to human osteosarcoma cells (MG-63) up to $30 \mathrm{wt}$ \% $\mathrm{GO}$, and a slight cytotoxicity is noticed at higher concentrations (Ordikhani et al. 2015).

Although further studies in vivo are still required to evaluate their efficacy in promoting cancer formation, the current studies suggest that the GO/CA-BC scaffolds might provide favorable microenvironment for the proliferation of cancer cells and may serve as an in vitro cancer cell model which is important for drug screening and cancer biology research (Xu et al.
2014; Horning et al. 2008). The results presented in this work may accelerate the application of GO in the scaffolds for the culture of cancer cells.

\section{Conclusions}

In summary, biomimetic scaffolds consisting of BC nanofibers and GO-incorporated CA microfibers were prepared by a combined technique of electrospinning and in situ biosynthesis. Our results showed that the mechanical properties of the GO/CA-BC scaffolds were improved by GO incorporation due to the interfacial interaction between $\mathrm{CA}$ and $\mathrm{GO}$ and the mechanical entanglement between GO/CA microfibers and BC nanofibers. Similarly, the hydrophilicity of the GO/CA-BC scaffolds was significantly improved by GO incorporation. In vitro cell studies including CCK-8 assay, fluorescence staining, and SEM observation revealed significantly better cellular adhesion, growth, and proliferation on and inside the GO/CA-BC-2 scaffold over the bare CA-BC scaffold, suggesting the positive impact of GO. Our results demonstrated that the GO/CA-BC-2 scaffold with optimum GO content exhibited improved mechanical properties and cancer cell attachment, spreading, and proliferation. We believe that the GO/CA-BC-2 scaffold has great potential as platform for the culture of cancer cells which is necessary for drug screening and cancer biology research.

Acknowledgments This work was supported by National Natural Science Foundation of China (Grant nos. 51572187, 51973058, 31660264, 31870963), the Key Research and Development Program of Jiangxi Province (No. 20192ACB80008), and the Youth Science Foundation of Jiangxi Province (No. 20181BAB216010), and Key Project of Natural Science Foundation of Jiangxi Province (No. 20161ACB20018).

Funding There has been no financial support for this work that could have influenced its outcome.

\section{Compliance with ethical standards}

Conflict of interest The authors declare that there are no known conflicts of interest associated with this publication. 


\section{References}

Aboamera NM, Mohamed A, Salama A, Osman TA, Khattab A (2018) An effective removal of organic dyes using surface functionalized cellulose acetate/graphene oxide composite nanofibers. Cellulose 25(7):4155-4166

Akhavan O, Ghaderi E, Shirazian SA, Rahighi R (2016) Rolled graphene oxide foams as three-dimensional scaffolds for growth of neural fibers using electrical stimulation of stem cells. Carbon 97:71-77. https://doi.org/10.1016/j.carbon. 2015.06.079

Ardeshirzadeh B, Anaraki NA, Irani M, Rad LR, Shamshiri S (2015) Controlled release of doxorubicin from electrospun $\mathrm{PEO} /$ chitosan/graphene oxide nanocomposite nanofibrous scaffolds. Mater Sci Eng, C 48:384-390. https://doi.org/10. 1016/j.msec.2014.12.039

Bae MS, Yang DH, Lee JB, Heo DN, Kwon YD, Youn IC, Choi K, Hong JH, Kim GT, Choi YS, Hwang EH, Kwon IK (2011) Photo-cured hyaluronic acid-based hydrogels containing simvastatin as a bone tissue regeneration scaffold. Biomaterials 32(32):8161-8171. https://doi.org/10.1016/j. biomaterials.2011.07.045

Baldino L, Sarno M, Cardea S, Irusta S, Ciambelli P, Santamaria J, Reverchon E (2015) Formation of cellulose acetategraphene oxide nanocomposites by supercritical $\mathrm{CO} 2$ assisted phase inversion. Ind Eng Chem Res 54(33):8147-8156

Blanton TN, Majumdar D (2013) Characterization of X-ray irradiated graphene oxide coatings using X-ray diffraction, $\mathrm{X}$-ray photoelectron spectroscopy, and atomic force microscopy. Powder Diffr 28(2):68-71

Cao L, Zhang F, Wang QG, Wu XF (2017) Fabrication of chitosan/graphene oxide polymer nanofiber and its biocompatibility for cartilage tissue engineering. Mater Sci Eng, C 79:697-701

Chang Y, Yang ST, Liu JH, Dong E, Wang Y, Cao A, Liu Y, Wang $H$ (2011) In vitro toxicity evaluation of graphene oxide on A549 cells. Toxicol Lett 200(3):201-210. https:// doi.org/10.1016/j.toxlet.2010.11.016

Chen H, Müller MB, Gilmore KJ, Wallace GG, Li D (2008) Mechanically strong, electrically conductive, and biocompatible graphene paper. Adv Mater 20(18):3557-3561

Collartdutilleul PY, Secret E, Panayotov I, Deville DPD, Martínpalma RJ, Torrescosta V, Martin M, Gergely C, Durand JO, Cunin F (2014) Adhesion and proliferation of human mesenchymal stem cells from dental pulp on porous silicon scaffolds. ACS Appl Mater Inter 6(3):1719-1728

Da C, Feng HB, Li JH (2012) Graphene oxide: preparation, functionalization, and electrochemical applications. Chem Rev 112(11):6027-6053

Depan D, Girase B, Shah JS, Misra RDK (2011) Structureprocess-property relationship of the polar graphene oxidemediated cellular response and stimulated growth of osteoblasts on hybrid chitosan network structure nanocomposite scaffolds. Acta Biomater 7(9):3432-3445. https://doi.org/10.1016/j.actbio.2011.05.019

Dorris GM, Gray DG (1978) Surface analysis of paper and wood fibres by ESCA. II. Surface composition of mechanical pulps. Cell Chem Technol 61:721-734
Du XY, Li Q, Wu G, Chen S (2019) Multifunctional micro/nanoscale fibers based on microfluidic spinning technology. Adv Mater. https://doi.org/10.1002/adma.201903733

Fan XB, Peng WC, Li Y, Li XY, Wang SL, Zhang GL, Zhang FB (2008) Deoxygenation of exfoliated graphite oxide under alkaline conditions: a green route to graphene preparation. Adv Mater 20(23):4490-4493. https://doi.org/ 10.1002/adma.200801306

Fu C, Bai HT, Zhu JQ, Niu ZH, Wang Y, Li JN, Yang XY, Bai YS (2017) Enhanced cell proliferation and osteogenic differentiation in electrospun PLGA/hydroxyapatite nanofibre scaffolds incorporated with graphene oxide. PLoS ONE. https://doi.org/10.1371/journal.pone.0188352

Galli C, Parisi L, Piergianni M, Smerieri A, Passeri G, Guizzardi S, Costa F, Lumetti S, Manfredi E, Macaluso GM (2016) Improved scaffold biocompatibility through anti-fibronectin aptamer functionalization. Acta Biomater 42:147-156

He JX, Tang YY, Wang SY (2007) Differences in morphological characteristics of bamboo fibres and other natural cellulose fibres: studies on X-ray diffraction, solid state 13C-CP/MAS NMR, and second derivative FTIR spectroscopy data. Iran Polym J 16(12):807-818

Horning JL, Sahoo SK, Vijayaraghavalu S, Dimitrijevic S, Vasir JK, Jain TK, Panda AK, Labhasetwar V (2008) 3-D tumor model for in vitro evaluation of anticancer drugs. Mol Pharm 5(5):849-862

Jin L, Zeng Z, Kuddannaya S, Yue D, Bao J, Wang Z, Zhang Y (2015) Synergistic effects of a novel free-standing reduced graphene oxide film and surface coating fibronectin on morphology, adhesion and proliferation of mesenchymal stem cells. J Mater Chem B 3(21):4338-4344. https://doi. org/10.1039/c5tb00295h

Kabiri R, Namazi H (2014) Nanocrystalline cellulose acetate (NCCA)/graphene oxide (GO) nanocomposites with enhanced mechanical properties and barrier against water vapor. Cellulose 21(5):3527-3539. https://doi.org/10. 1007/s10570-014-0366-4

Kazantseva J, Ivanov R, Gasik M, Neuman T, Hussainova I (2018) Graphene-augmented nanofiber scaffolds trigger gene expression switching of four cancer cell types. ACS Biomater Sci Eng 4(5):1622-1629. https://doi.org/10. 1021/acsbiomaterials.8b00228

Kenry Chaudhuri PK, Loh KP, Lim CT (2016) Selective accelerated proliferation of malignant breast cancer cells on planar graphene oxide films. ACS Nano 10(3):3424-3434. https://doi.org/10.1021/acsnano. 5 b07409

Kenry Lee WC, Loh KP, Lim CT (2018) When stem cells meet graphene: opportunities and challenges in regenerative medicine. Biomaterials 155:236-250. https://doi.org/10. 1016/j.biomaterials.2017.10.004

Kim J, Yang K, Lee JS, Hwang YH, Park H-J, Park KI, Lee DY, Cho S-W (2017) Enhanced self-renewal and accelerated differentiation of human fetal neural stem cells using graphene oxide nanoparticles. Macromol Biosci 17(8):1600540. https://doi.org/10.1002/mabi.201600540

Layek RK, Ramakrishnan KR, Sarlin E, Orell O, Kanerva M, Vuorinen J, Honkanen M (2018) Layered structure graphene oxide/methylcellulose composites with enhanced 
mechanical and gas barrier properties. J Mater Chem A 6(27):13203-13214

Li G, Zhao Y, Zhang L, Gao M, Kong Y, Yang Y (2016) Preparation of graphene oxide/polyacrylamide composite hydrogel and its effect on schwann cells attachment and proliferation. Colloid Surf B 143:547-556. https://doi.org/ 10.1016/j.colsurfb.2016.03.079

Liang CY, Luo YC, Yang GD, Xia D, Liu L, Zhang X, Wang H (2018) Graphene oxide hybridized nHAC/PLGA scaffolds facilitate the proliferation of MC3T3-E1 cells. Nanoscale Res Lett 13:1-10. https://doi.org/10.1186/s11671-0182432-6

Liao KH, Lin YS, Macosko CW, Haynes CL (2011) Cytotoxicity of graphene oxide and graphene in human erythrocytes and skin fibroblasts. ACS Appl Mater Inter 3(7):2607-2615. https://doi.org/10.1021/am200428v

Liu HQ, Hsieh YL (2002) Ultrafine fibrous cellulose membranes from electrospinning of cellulose acetate. J Polym Sci, Part B: Polym Phys 40(18):2119-2129

Liu Y, Park M, Shin HK, Pant B, Choi J, Park YW, Lee JY, Park S-J, Kim H-Y (2014) Facile preparation and characterization of poly(vinyl alcohol)/chitosan/graphene oxide biocomposite nanofibers. J Ind Eng Chem 20(6):4415-4420. https://doi.org/10.1016/j.jiec.2014.02.009

Liu X, Shen H, Song S, Chen W, Zhang Z (2017) Accelerated biomineralization of graphene oxide-incorporated cellulose acetate nanofibrous scaffolds for mesenchymal stem cell osteogenesis. Colloid Surf B 159:251-258

Luo H, Ao H, Li G, Li W, Xiong G, Zhu Y, Wan Y (2017) Bacterial cellulose/graphene oxide nanocomposite as a novel drug delivery system. Curr Appl Phys 17(2):249-254

Luo H, Dong J, Yao F, Yang Z, Li W, Wang J, Xu X, Hu J, Wan Y (2018a) Layer-by-layer assembled bacterial cellulose/graphene oxide hydrogels with extremely enhanced mechanical properties. Nano Micro Lett 10(3):42

Luo H, Xiong P, Xie J, Yang Z, Huang Y, Hu J, Wan Y, Xu Y (2018b) Uniformly dispersed freestanding carbon nanofiber/graphene electrodes made by a scalable biological method for high-performance flexible supercapacitors. Adv Funct Mater 28:1803075. https://doi.org/10.1002/ adfm.201803075

Mazaheri M, Akhavan O, Simchi A (2014) Flexible bactericidal graphene oxide-chitosan layers for stem cell proliferation. Appl Surf Sci 301:456-462. https://doi.org/10.1016/j. apsusc.2014.02.099

Mohammadrezaei D, Golzar H, Rezai Rad M, Omidi M, Rashedi H, Yazdian F, Khojasteh A, Tayebi L (2018) In vitro effect of graphene structures as an osteoinductive factor in bone tissue engineering: a systematic review. J Biomed Mater Res, Part A 106(8):2284-2343. https://doi. org/10.1002/jbm.a.36422

Mu J, Zhou Y, Bu X, Zhang T (2014) Synthesis and characterization of three-dimensional porous graphene oxide/sodium alginate scaffolds with enhanced mechanical properties. Mater Express 4(5):429-434

Ordikhani F, Ramezani Farani M, Dehghani M, Tamjid E, Simchi A (2015) Physicochemical and biological properties of electrodeposited graphene oxide/chitosan films with drug-eluting capacity. Carbon 84:91-102. https://doi.org/ 10.1016/j.carbon.2014.11.052
Park S, Ruoff RS (2009) Chemical methods for the production of graphenes. Nat Nanotechnol 4(4):217-224

Pinto AM, Cabral J, Tanaka DAP, Mendes AM, Magalhães FD (2013) Effect of incorporation of graphene oxide and graphene nanoplatelets on mechanical and gas permeability properties of poly (lactic acid) films. Polym Int 62(1):33-40

Potts JR, Dreyer DR, Bielawski CW, Ruoff RS (2011) Graphene-based polymer nanocomposites. Polymer 52(1):5-25

Qi YY, Tai ZX, Sun DF, Chen JT, Ma HB, Yan XB, Liu B, Xue QJ (2013) Fabrication and characterization of poly(vinyl alcohol)/graphene oxide nanofibrous biocomposite scaffolds. J Appl Polym Sci 127(3):1885-1894. https://doi.org/ 10.1002/app.37924

Rho KS, Jeong L, Lee G, Seo B-M, Park YJ, Hong S-D, Roh S, Cho JJ, Park WH, Min B-M (2006) Electrospinning of collagen nanofibers: effects on the behavior of normal human keratinocytes and early-stage wound healing. Biomaterials 27(8):1452-1461. https://doi.org/10.1016/j. biomaterials.2005.08.004

Shao WL, Sang F, Shu jie HE, Qian JY, Qiang LI, Wang Q (2016) Preparation and characterization of bone-like biomimetic electrospun poly L-lactic acid nanofibers enhanced by graphene oxide. J Mater Sci Eng 34(4):535-539

Si H, Luo H, Xiong G, Yang Z, Raman SR, Guo R, Wan Y (2014) One-step in situ biosynthesis of graphene oxidebacterial cellulose nanocomposite hydrogels. Macromol Rapid Commun 35(9):1706-1711

Sims-Mourtada J, Niamat RA, Samuel S, Eskridge C, Kmiec EB (2014) Enrichment of breast cancer stem-like cells by growth on electrospun polycaprolactone-chitosan nanofiber scaffolds. Int J Nanomed 9:995-1003. https://doi.org/ 10.2147/ijn.s55720

Soldano C, Mahmood A, Dujardin E (2010) Production, properties and potential of graphene. Carbon 48(8):2127-2150

Stankovich S, Dikin DA, Piner RD, Kohlhaas KA, Kleinhammes A, Jia Y, Wu Y, Nguyen ST, Ruoff RS (2007) Synthesis of graphene-based nanosheets via chemical reduction of exfoliated graphite oxide. Carbon 45(7):1558-1565. https://doi.org/10.1016/j.carbon.2007. 02.034

Tokoh C, Takabe K, Fujita M, Saiki H (1998) Cellulose synthesized by acetobacter xylinum in the presence of acetyl glucomannan. Cellulose 5(4):249-261. https://doi.org/10. 1023/a:1009211927183

Uddin ME, Layek RK, Kim HY, Kim NH, Hui D, Lee JH (2016) Preparation and enhanced mechanical properties of noncovalently-functionalized graphene oxide/cellulose acetate nanocomposites. Compos Part B Eng 90:223-231

Verdejo R, Bernal MM, Romasanta LJ, Lopez-Manchado MA (2011) Graphene filled polymer nanocomposites. J Mater Chem 21(10):3301-3310

Wan YZ, Hong L, Jia SR, Huang Y, Zhu Y, Wang YL, Jiang HJ (2006) Synthesis and characterization of hydroxyapatitebacterial cellulose nanocomposites. Compos Sci Technol 66(11-12):1825-1832

Wan YZ, Huang Y, Yuan CD, Raman S, Zhu Y, Jiang HJ, He F, Gao C (2007) Biomimetic synthesis of hydroxyapatite/ bacterial cellulose nanocomposites for biomedical 
applications. Mater Sci Eng, C 27(4):855-864. https://doi. org/10.1016/j.msec.2006.10.002

Wan YZ, Yang ZW, Xiong GY, Guo RS, Liu Z, Luo HL (2015) Anchoring $\mathrm{Fe} 3 \mathrm{O} 4$ nanoparticles on three-dimensional carbon nanofibers toward flexible high-performance anodes for lithium-ion batteries. J Power Sources 294:414-419

Wan YZ, Cui T, Zhang QC, Yang ZW, Yao FL, Luo HL (2018) Submicrofiber-incorporated 3D bacterial cellulose nanofibrous scaffolds with enhanced cell performance. Macromol Mater Eng 303(11):1800316. https://doi.org/10.1002/ mame.201800316

Wojtoniszak M, Chen X, Kalenczuk RJ, Wajda A, Lapczuk J, Kurzewski M, Drozdzik M, Chu PK, Borowiak-Palen E (2012) Synthesis, dispersion, and cytocompatibility of graphene oxide and reduced graphene oxide. Colloid Surf B 89:79-85. https://doi.org/10.1016/j.colsurfb.2011.08. 026
Xu X, Farach-Carson MC, Jia X (2014) Three-dimensional in vitro tumor models for cancer research and drug evaluation. Biotech Adv 32(7):1256-1268

Xu Y, Cui W, Zhang Y, Zhou P, Gu Y, Shen X, Li B, Chen L (2017) Hierarchical micro/nanofibrous bioscaffolds for structural tissue regeneration. Adv Healthc Mater 6(13):1601457. https://doi.org/10.1002/adhm.201601457

Young RJ, Kinloch IA, Gong L, Novoselov KS (2012) The mechanics of graphene nanocomposites: a review. Compos Sci Technol 72(12):1459-1476

Zhu Y, Murali S, Cai W, Li X, Suk JW, Potts JR, Ruoff RS (2010) Graphene and graphene oxide: synthesis, properties, and applications. Adv Mater 22(35):3906-3924

Publisher's Note Springer Nature remains neutral with regard to jurisdictional claims in published maps and institutional affiliations. 